Bull. Chem. Soc. Ethiop. 2016, 30(2), 263-272.

Printed in Ethiopia

DOI: http://dx.doi.org/10.4314/bcse.v30i2.10

ISSN 1011-3924

(c) 2016 Chemical Society of Ethiopia

\title{
SYNTHESES AND CHARACTERIZATIONS OF THE CYANIDE-BRIDGED HETERONUCLEAR POLYMERIC COMPLEXES WITH 2-ETHYLIMIDAZOLE
}

\author{
Dursun Karaağaç ${ }^{1 *}$ and Güneş Süheyla Kürkçüoğlu² \\ ${ }^{1}$ Ulubatlı Hasan Anatolian High School, 16320 Bursa, Turkey \\ ${ }^{2}$ Eskişehir Osmangazi University, Faculty of Arts and Sciences, Department of Physics, 26480 \\ Eskişehir, Turkey
}

(Received October 28, 2015; revised June 25, 2016)

\begin{abstract}
Three new cyano-bridged heteronuclear polymeric complexes, $\left[\mathrm{Cu}(\mathrm{etim})_{3} \mathrm{Ni}(\mathrm{CN})_{4}\right]_{\mathrm{n}}$, $\left\{\left[\mathrm{Zn}(\text { etim })_{3} \mathrm{Ni}(\mathrm{CN})_{4}\right] \cdot \mathrm{H}_{2} \mathrm{O}\right\}_{\mathrm{n}}$ and $\left[\mathrm{Cd}(\text { etim })_{2} \mathrm{Ni}(\mathrm{CN})_{4}\right]_{\mathrm{n}}($ etim $=2$-ethylimidazole, hereafter abbreviated as $\mathrm{Cu}-\mathrm{Ni}-$ etim, $\mathrm{Zn}-\mathrm{Ni}$-etim and $\mathrm{Cd}-\mathrm{Ni}$-etim) have been prepared in powder form and characterized by FT-IR and Raman spectroscopies, thermal (TG, DTG and DTA) and elemental analyses. The spectral features of the complexes suggest that the $\mathrm{Ni}$ (II) ion is four coordinate with four cyanide-carbon atoms in a square planar geometry, whereas the $\mathrm{Cu}(\mathrm{II})$ and the $\mathrm{Zn}(\mathrm{II})$ ions of the $\mathrm{Cu}-\mathrm{Ni}$-etim and the $\mathrm{Zn}-\mathrm{Ni}$-etim complexes are completed by nitrogen atoms of two cyano groups of $\left[\mathrm{Ni}(\mathrm{CN})_{4}\right]^{2-}$ coordinated to the adjacent $\mathrm{M}$ (II) ions and three nitrogen atoms of the etim ligands. The $\mathrm{Cd}(\mathrm{II})$ ion of the $\mathrm{Cd}-\mathrm{Ni}$-etim complex is six-coordinate, completed with the two nitrogen atoms of the etim ligands and the four nitrogen atoms from bridging cyano groups. Polymeric structures of the $\mathrm{Cu}-\mathrm{Ni}-$ etim and the $\mathrm{Zn}-\mathrm{Ni}$-etim complexes are $1 \mathrm{D}$ coordination polymer, while complex the $\mathrm{Cd}-\mathrm{Ni}-$ etim presents a $2 \mathrm{D}$ network. The thermal decompositions in the temperature range $30-700{ }^{\circ} \mathrm{C}$ of the complexes were investigated in the static air atmosphere.
\end{abstract}

KEY WORDS: Tetracyanonickelate(II) complex, 2-Ethylimidazole complex, Cyanide-bridged complex, Vibration spectra, Thermal analysis

\section{INTRODUCTION}

Coordination polymers include metal ions linked by coordinated ligands into an endless array. This endless net must be defined by coordination bonds. Coordination polymers can form surprising supramolecular contractions which indicate regulation one, two, three dimensional due to coordination bonds. Cyanometallate complexes in coordination polymers have an important place and they are known to be among the first coordination compounds that has been prepared, studied, described and used up to now. Therefore, they have still continued actuality in the coordination chemistry [1-3]. Additionally, cyanometallate complexes exhibiting polymeric structures have found many application areas such as electrical conductivity [4], molecular sieves and ion exchange materials [5], molecular magnetic nanowires [6] and host-guest systems [7].

Cyanide anions having binding ability to various center atoms are used in the synthesis of one, two or three dimensional structures in organometallic and coordination chemistry. Cyanometallate building blocks containing cyanide groups, $\left[\mathrm{M}(\mathrm{CN})_{\mathrm{x}}\right]^{\mathrm{n}-}$ such as $\left[\mathrm{Ni}(\mathrm{CN})_{6}\right]^{4-}$, $\left[\mathrm{Ni}(\mathrm{CN})_{4}\right]^{2-},\left[\mathrm{Pd}(\mathrm{CN})_{4}\right]^{2-},\left[\mathrm{Pt}(\mathrm{CN})_{4}\right]^{2-}$ and $\left[\mathrm{Au}(\mathrm{CN})_{4}\right]^{-}$have been extensively utilized to form multidimensional networks $[3,8-10]$. This is due to fact that both the carbon and the nitrogen ends of the cyanide ion act as Lewis bases that can coordinate two different metal cations acting as the corresponding Lewis acids. Accordingly, cyanometallate readily forms coordination polymers when reacted with transition-metal cations and can promote strong magnetic exchange. However, there have been many studies on octahedral $\left[\mathrm{M}(\mathrm{CN})_{6}\right]^{\mathrm{n}-\mathrm{r}}$ but little interest has been drawn to square-planar $\left[\mathrm{M}(\mathrm{CN})_{4}\right]^{\mathrm{n}-\mathrm{C}}[\mathrm{M}(\mathrm{II})=\mathrm{Ni}$, Pd or Pt] bridging units [11-13]. The well-known Hofmann-type structures consist of building blocks $\left[\mathrm{M}(\mathrm{CN})_{4}\right]^{\mathrm{n}-}$ and the general

*Corresponding author. E-mail: ddkaraagac@hotmail.com 
formula is shown as $\left[\mathrm{M}(\mathrm{L})_{\mathrm{x}} \mathrm{M}^{\prime}(\mathrm{CN})_{4}\right]_{\mathrm{n}}$ [where $\mathrm{x}=2$ or $1 ; \mathrm{M}(\mathrm{II})=\mathrm{Mn}, \mathrm{Fe}, \mathrm{Co}, \mathrm{Ni}, \mathrm{Cu}, \mathrm{Zn}$ or Cd ; $\mathrm{M}^{\prime}(\mathrm{II})=\mathrm{Ni}, \mathrm{Pd}$ or Pt] [14].

In our previous studies, we reported the tetracyanonickelate(II) or tetracyanopalladate(II) complexes with imidazole [15], N-methylimidazole [16], 2-methylimidazole [15, 17], 4(5)methylimidazole [18] and 1-ethylimidazole [19]. In this study, three new complexes using 2ethylimidazole molecule, $\left[\mathrm{Cu}(\text { etim })_{3} \mathrm{Ni}(\mathrm{CN})_{4}\right]_{\mathrm{n}}, \quad\left\{\left[\mathrm{Zn}(\text { etim })_{3} \mathrm{Ni}(\mathrm{CN})_{4}\right] \cdot \mathrm{H}_{2} \mathrm{O}\right\}_{\mathrm{n}} \quad$ and $\left[\mathrm{Cd}(\text { etim })_{2} \mathrm{Ni}(\mathrm{CN})_{4}\right]_{\mathrm{n}}$, were synthesized and investigated by vibrational spectral (FT-IR and Raman), thermal and elemental analyses techniques.

\section{EXPERIMENTAL}

\section{Materials}

Nickel(II) chloride hexahydrate $\left(\mathrm{NiCl}_{2} \cdot 6 \mathrm{H}_{2} \mathrm{O}-97 \%\right.$, Riedel-de Haen), copper(II) chloride dihydrate $\left(\mathrm{CuCl}_{2} \cdot 2 \mathrm{H}_{2} \mathrm{O}-99 \%\right.$, Merck), zinc(II) chloride $\left(\mathrm{ZnCl}_{2}-96 \%\right.$, Merck), cadmium(II) chloride hemi(pentahydrate) $\left(\mathrm{CdCl}_{2} \cdot 2.5 \mathrm{H}_{2} \mathrm{O}-99 \%\right.$, Across Organics), potassium cyanide $(\mathrm{KCN}-$ $96 \%$, Sigma-Aldrich) and 2-ethylimidazole $\left(\mathrm{C}_{5} \mathrm{H}_{8} \mathrm{~N}_{2}-98 \%\right.$, Sigma-Aldrich) from commercial sources were used as received.

\section{Syntheses of the complexes}

To water solution of nickel(II) chloride hexahydrate $(1 \mathrm{mmol}, 0.238 \mathrm{~g})$ was added a solution of potassium cyanide $\left(4 \mathrm{mmol}, 0.260 \mathrm{~g}\right.$ ) in water solution and $\mathrm{K}_{2}\left[\mathrm{Ni}(\mathrm{CN})_{4}\right] \cdot \mathrm{H}_{2} \mathrm{O}$ complex was obtained as crystallized. The $\mathrm{K}_{2}\left[\mathrm{Ni}(\mathrm{CN})_{4}\right] \cdot \mathrm{H}_{2} \mathrm{O}(1 \mathrm{mmol}, 0.259 \mathrm{~g})$ complex was dissolved in distilled water, then $1 \mathrm{mmol}$ of the metal(II) chloride $\left(\mathrm{CuCl}_{2} \cdot 2 \mathrm{H}_{2} \mathrm{O}=0.170 \mathrm{~g}, \mathrm{ZnCl}_{2}=0.136 \mathrm{~g}\right.$ and $\mathrm{CdCl}_{2} \cdot 2.5 \mathrm{H}_{2} \mathrm{O}=0.228 \mathrm{~g}$ ) dissolved in distilled water were added to this solution under stirring and the $\mathrm{M}\left[\mathrm{Ni}(\mathrm{CN})_{4}\right] \cdot \mathrm{H}_{2} \mathrm{O}[\mathrm{M}=\mathrm{Cu}(\mathrm{II}), \mathrm{Zn}(\mathrm{II})$ or $\mathrm{Cd}(\mathrm{II})]$ complexes obtained were filtered and dried in air. To $1 \mathrm{mmol}$ of $\mathrm{M}\left[\mathrm{Ni}(\mathrm{CN})_{4}\right] \cdot \mathrm{H}_{2} \mathrm{O} \quad \mathrm{Cu}\left[\mathrm{Ni}(\mathrm{CN})_{4}\right] \cdot \mathrm{H}_{2} \mathrm{O}=0.244 \mathrm{~g}$, $\mathrm{Zn}\left[\mathrm{Ni}(\mathrm{CN})_{4}\right] \cdot \mathrm{H}_{2} \mathrm{O}=0.246 \mathrm{~g}$ or $\mathrm{Cd}\left[\mathrm{Ni}(\mathrm{CN})_{4}\right] \cdot \mathrm{H}_{2} \mathrm{O}=0.293 \mathrm{~g}$ \} aqueous solution, $2 \mathrm{mmol}$ of the etim $(0.192 \mathrm{~g})$ dissolved in ethyl alcohol were slightly added to this solution under stirring. The final mixtures were stirred for $3 \mathrm{~h}$ at room temperature. The products obtained were filtered and washed with water, ethanol and ether, respectively, and dried in air. The freshly prepared complexes were analyzed for $\mathrm{C}, \mathrm{H}$ and $\mathrm{N}$ with the following results: Anal. found (calcd.) (\%) for $\mathrm{C}_{19} \mathrm{H}_{24} \mathrm{~N}_{10} \mathrm{NiCu}\left(\mathrm{M}_{\mathrm{w}}=514.70 \mathrm{~g} / \mathrm{mol}\right)$ : C, 43.94 (44.34); H, 4.90 (4.70); N, 26.84 (27.21); for $\mathrm{C}_{19} \mathrm{H}_{26} \mathrm{~N}_{10} \mathrm{ONiZn}\left(\mathrm{M}_{\mathrm{w}}=534.56 \mathrm{~g} / \mathrm{mol}\right)$ : C, 42.50 (42.69); H, 4.91 (4.90); N, 25.37 (26.20); for $\mathrm{C}_{14} \mathrm{H}_{16} \mathrm{~N}_{8} \mathrm{NiCd}\left(\mathrm{M}_{\mathrm{w}}=467.43 \mathrm{~g} / \mathrm{mol}\right)$ : C, 35.18 (35.97); H, 3.44 (3.45); N, 23.91 (23.97).

\section{Measurements}

Elemental analyses were performed using a CHNS-932 (LECO) analyzer for C, $\mathrm{H}$ and $\mathrm{N}$ at the Middle East Technical University Central Laboratory in Ankara, Turkey. The FT-IR spectra of the etim and the complexes were recorded as $\mathrm{KBr}$ pellets in the range of $4000-400 \mathrm{~cm}^{-1}\left(2 \mathrm{~cm}^{-1}\right.$ resolution) on a Perkin Elmer 100 FT-IR spectrometer which was calibrated using polystyrene and $\mathrm{CO}_{2}$ bands. The Raman spectra of the complexes were recorded in the range of 4000-250 $\mathrm{cm}^{-1}$ on a Bruker Senterra Dispersive Raman instrument using laser excitation of $785 \mathrm{~nm}$. A Perkin Elmer Diamond TG/DTA thermal analyzer was used to record simultaneous TG, DTG and DTA curves of the complexes in a static air atmosphere at a heating rate of $10 \mathrm{~K} \mathrm{~min}^{-1}$ in the temperature range $30-700{ }^{\circ} \mathrm{C}$ using platinum crucibles. 


\section{RESULTS AND DISCUSSION}

\section{2-Ethylimidazole vibrations}

The etim molecule containing two nitrogen atoms can donate electrons. The nitrogen atom can coordinate with a transition-metal ion and form complexes with different properties. The molecular structure of the etim is shown in Scheme 1.

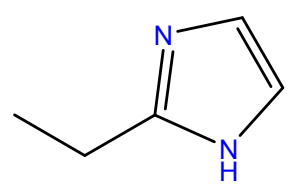

Scheme 1. The molecular structure of the etim.

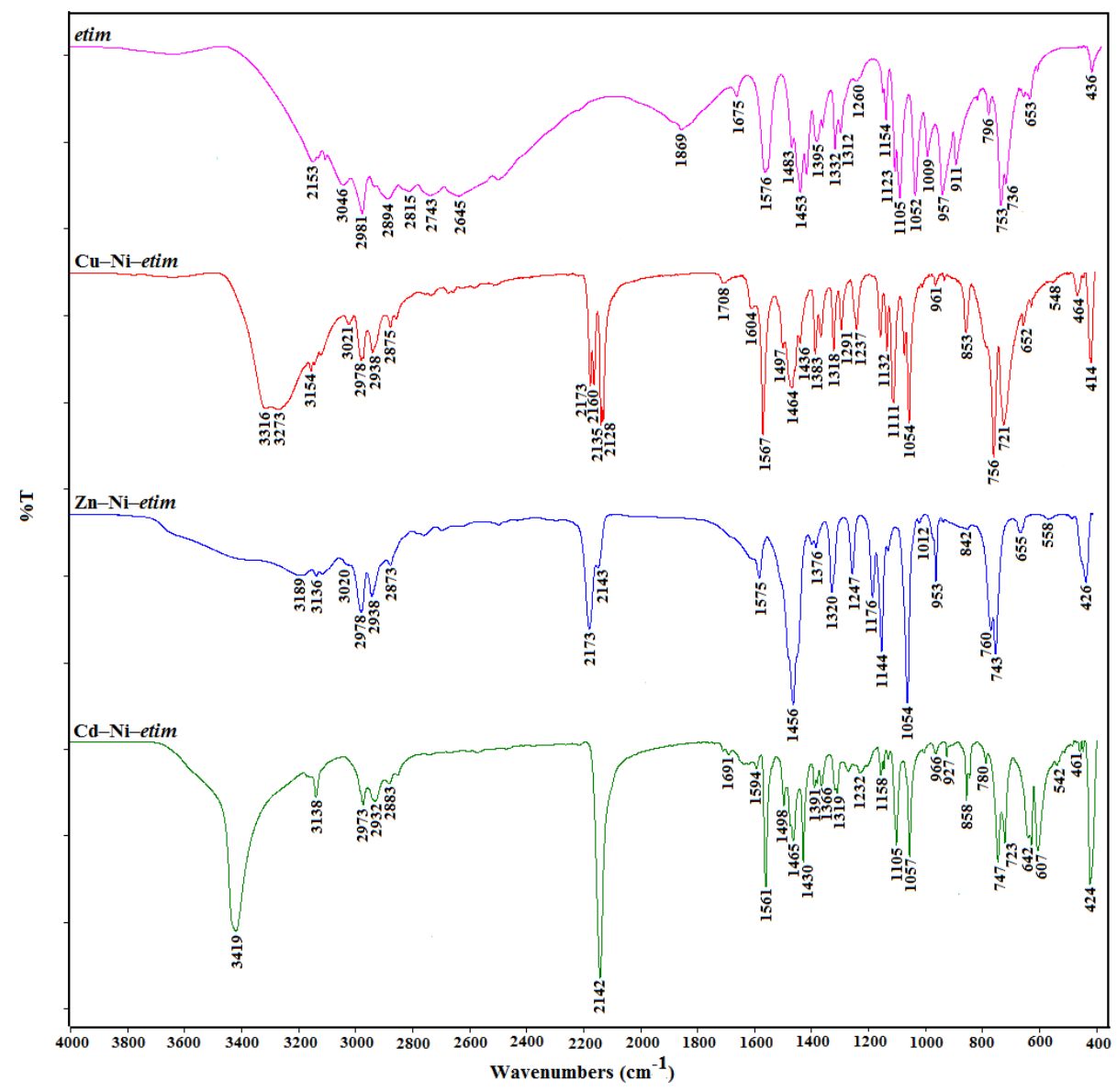

Figure 1. The FT-IR spectra of the etim and the complexes.

Bull. Chem. Soc. Ethiop. 2016, 30(2) 


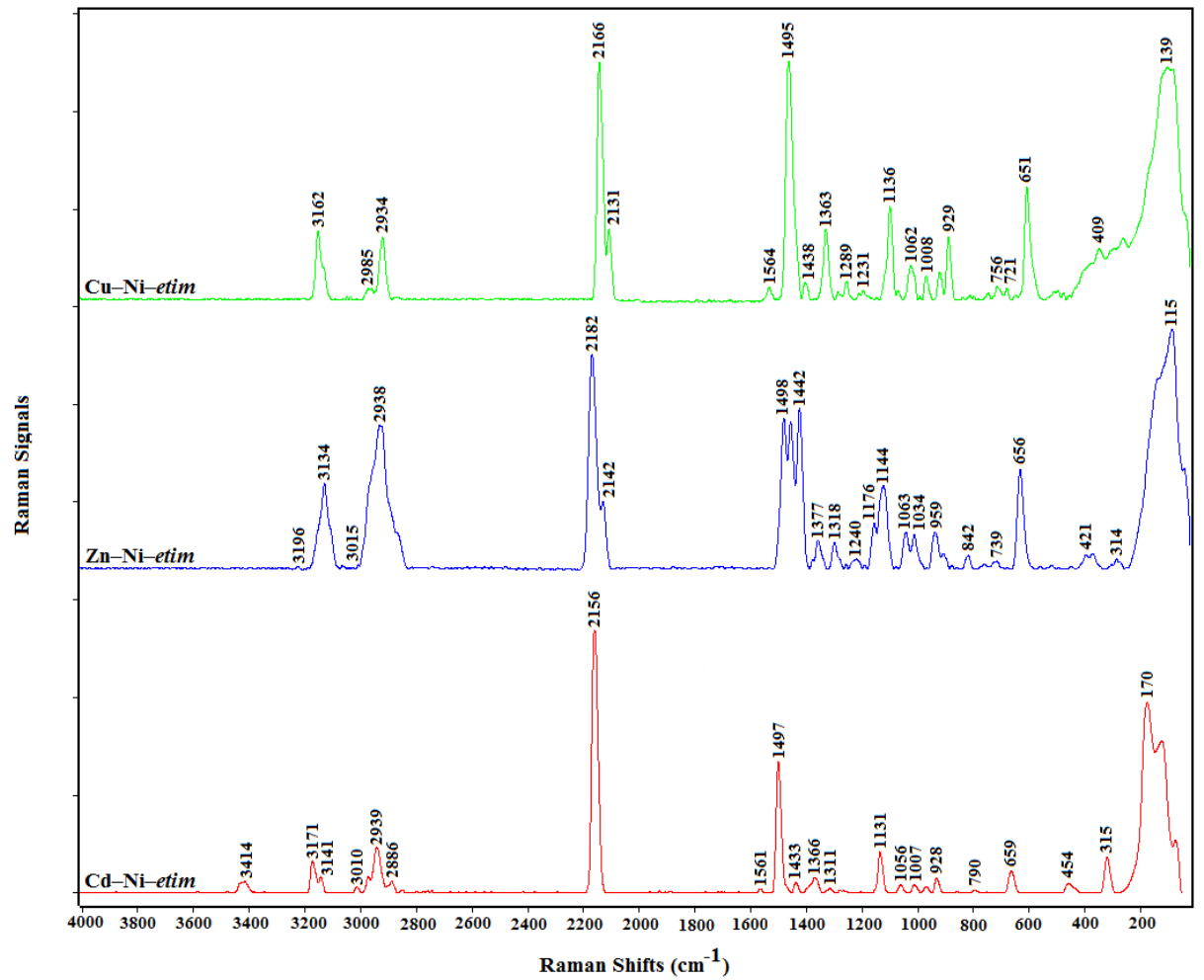

Figure 2. The Raman spectra of the complexes.

The FT-IR and Raman spectra of all of the complexes are given in Figures 1 and 2, respectively. The tentative assignments of the modes of vibration of the free etim and that of the etim molecules in the complexes are listed in Table 1. The FT-IR spectrum of the Zn-Ni-etim complex contains absorption bands originating from $v_{(\mathrm{OH})}$ and $\delta_{(\mathrm{OH})}$ vibrations. In the $\mathrm{Zn}$-Ni-etim complex, the absorption bands observed from 3700 to $3328 \mathrm{~cm}^{-1}$ may be attributed to the $v_{(\mathrm{OH})}$ stretching mode of the water molecule. The $\delta_{(\mathrm{OH})}$ bending mode is also observed at about 1600 $\mathrm{cm}^{-1}$ in the $\mathrm{Zn}-\mathrm{Ni}$-etim complex. In all the heterocyclic compounds, the $v_{(\mathrm{NH})}$ stretching vibrations are typically located in the region $3500-3300 \mathrm{~cm}^{-1}[20]$. However, we have observed the $v_{(\mathrm{NH})}$ stretching vibrations of the free etim at $c a .3153 \mathrm{~cm}^{-1}$ in FT-IR spectrum. The $v_{(\mathrm{NH})}$ stretching vibrations of the etim ligand in the FT-IR and Raman spectra of the complexes were found to be between $3414 \mathrm{~cm}^{-1}$ and $3162 \mathrm{~cm}^{-1}$ and shifted to a higher frequency than the corresponding value of the etim molecule. This shift shows that the etim acts as monodentate ligand through the nitrogen atom of the imidazole ring. The in-plane $\left(1375 \mathrm{~cm}^{-1}\right)$ and out-ofplane $\left(753 \mathrm{~cm}^{-1}\right)$ bending vibrations of etim ligand are also supported to these shifts. The $v_{(\mathrm{CH})}$ stretching vibrations arising from imidazole ring of the free etim are assigned at about $3136 \mathrm{~cm}^{-1}$ in the FT-IR spectrum and these vibrations are observed in the frequency range of 3171-3134 $\mathrm{cm}^{-1}$ in the vibration spectra of the complexes. As seen in Table 1, the etim ligand shows infrared bands in the $3110-2894 \mathrm{~cm}^{-1}$ region which are assigned to the $v_{(\mathrm{CH} 3)}$ and $v_{(\mathrm{CH} 2)}$ asymmetric and symmetric stretching frequencies, respectively. The absorption bands of the $v_{(\mathrm{CH} 3)}$ and $v_{(\mathrm{CH} 2)}$ groups in the complexes are observed in the region 3141-2932 $\mathrm{cm}^{-1}$, and 
significantly shifted to lower or higher frequencies compared to that of the free ligand. The $\rho_{(\mathrm{CH} 2)}$ in-plane rocking vibration frequency is identified at $1105 \mathrm{~cm}^{-1}$ in the FT-IR spectrum of the etim and shifted to higher frequency compared to the free ligand in the complexes. The $\delta_{(\mathrm{CH})}$ in-plane and $\omega_{(\mathrm{CH} 3)}$ out of plane bending modes are found at 1165 and $1123 \mathrm{~cm}^{-1}$ in the FT-IR spectrum, respectively. The bands obtained at 1009 and $957 \mathrm{~cm}^{-1}$ in FT-IR spectrum of the etim are assigned to $\mathrm{CH}_{3}$ in-plane and out-of plane rocking modes, respectively. The $v_{(\mathrm{C}=\mathrm{N})}$ stretching vibration in the imidazole is assigned to the wavenumber $1675 \mathrm{~cm}^{-1}$ in FT-IR spectrum. The observed bands at 1576, 1483 and $1453 \mathrm{~cm}^{-1}$ in FT-IR spectrum of the etim ligand are assigned to $v_{(\mathrm{C}-\mathrm{N})}$ stretching vibration. The $v_{(\mathrm{CC})}$ stretching vibrations are observed at 1431 and $1395 \mathrm{~cm}^{-1}$ in FT-IR spectrum and these vibrations in the complexes shifted to higher frequency region around $1-11 \mathrm{~cm}^{-1}$ at $1431 \mathrm{~cm}^{-1}$ and lower frequency region around $1-12 \mathrm{~cm}^{-1}$ at $1395 \mathrm{~cm}^{-1}$, compared with the free etim molecule. These shifts can be explained as the coupling of the internal modes of the etim molecule with $\mathrm{M}-\mathrm{N}(\mathrm{etim})$ vibrations. Similar shifts on coordination have been observed in the vibration spectra of the other metal-coordinated imidazole complexes [15-21].

$\left[\mathrm{Ni}(\mathrm{CN})_{4}\right]^{2-}$ group vibrations

The modes of vibration of the $\left[\mathrm{Ni}(\mathrm{CN})_{4}\right]^{2-}$ group of the complexes are given in Table 2. In order to assign the bands attributable to the $\left[\mathrm{Ni}(\mathrm{CN})_{4}\right]^{2-}$ ion in the spectra, we refer to the work of McCullough et al. who presented vibrational data for the salt $\mathrm{Na}_{2} \mathrm{Ni}(\mathrm{CN})_{4}$ in the solid state [22]. Symmetrical vibration band $\left[v(\mathrm{CN}), \mathrm{E}_{\mathrm{u}}\right]$ of complex $\mathrm{K}_{2}\left[\mathrm{Ni}(\mathrm{CN})_{4}\right] \cdot \mathrm{H}_{2} \mathrm{O}$ is observed at $2120 \mathrm{~cm}^{-1}$, $A_{1 g}$ and $B_{1 g}$ symmetry stretching vibrations arising from Raman active $v_{(C=N)}$ vibration are observed at 2160 and $2137 \mathrm{~cm}^{-1}$. In FT-IR and Raman spectra of the complexes the dominant feature is represented by strong and sharp well identifiable absorption bands due to the $v_{(\mathrm{C}=\mathrm{N})}$ stretching vibrations $[1,23]$. The cyanide groups exhibit strong and sharp absorption bands in vibrational spectra between 2200 and $2100 \mathrm{~cm}^{-1}$, due to the stretching vibrations of the cyanide group. The $v_{(\mathrm{C} \equiv \mathrm{N})}$ stretching vibrations are an important tool to distinguish between terminal and bridging character in the cyanide complexes. The bridging cyanide frequencies in cyano-bridged complexes are usually observed at higher wavenumbers than those of the terminal cyanide. Shifting to higher wavenumbers of the cyanide stretching frequency upon the formation of cyanide bridges occur due to both the kinematic coupling and increasing the $\mathrm{CN}$ force constant when a second metal center is attached to the CN unit. In the FT-IR spectra of the complexes, the $v_{(\mathrm{C} \equiv \mathrm{N})}$ absorption bands are observed at $2173,2160,2135$ and $2128 \mathrm{~cm}^{-1}$ (for the $\mathrm{Cu}-\mathrm{Ni}-$ etim), 2173 and $2143 \mathrm{~cm}^{-1}$ (for the $\mathrm{Zn}-\mathrm{Ni}$-etim) and $2142 \mathrm{~cm}^{-1}$ (for the $\mathrm{Cd}-\mathrm{Ni}-$ etim). Thus, in the $\mathrm{Cu}-\mathrm{Ni}$-etim complex, the two high wavenumbers, $2173 \mathrm{~cm}^{-1}$ and $2160 \mathrm{~cm}^{-1}$, correspond to the bridging cyanide and the two low wavenumbers, $2135 \mathrm{~cm}^{-1}$ and $2128 \mathrm{~cm}^{-1}$, correspond to the terminal cyanide. Additionally, in the $\mathrm{Zn}-\mathrm{Ni}$-etim complex, the two $\mathrm{v}_{(\mathrm{CN})}$ bands, which appeared at 2173 and $2143 \mathrm{~cm}^{-1}$, can be assigned to the bridging and terminal cyanide groups, respectively. However, the $\mathrm{Cd}-\mathrm{Ni}$-etim complex contains only one $v_{(\mathrm{C}=\mathrm{N})}$ absorption band at $2142 \mathrm{~cm}^{-1}$ belonging to the bridging cyano groups. From the FT-IR spectra of the complexes, it is determined that the $v_{(\mathrm{C}=\mathrm{N})}$ stretching vibrational mode of the cyanide has shifted to approximately $22-53 \mathrm{~cm}^{-1}$ higher frequency (see Table 2). The cyanide stretching bands in the Raman spectra of the complexes were observed at 2166 and $2131 \mathrm{~cm}^{-1}$ in the $\mathrm{Cu}-\mathrm{Ni}$-etim, at 2182 and $2142 \mathrm{~cm}^{-1}$ in the $\mathrm{Zn}-\mathrm{Ni}-$ etim, at $2156 \mathrm{~cm}^{-1}$ in the Cd-Ni-etim, respectively. On the other hand, the in-plane bending vibrational mode, $\delta_{(\mathrm{NiCN})}$ was observed at $414 \mathrm{~cm}^{-1}$ in the FT-IR spectrum of the $\mathrm{K}_{2}\left[\mathrm{Ni}(\mathrm{CN})_{4}\right] \cdot \mathrm{H}_{2} \mathrm{O}$ which was shifted to the higher frequency range around 1-12 $\mathrm{cm}^{-1}$ for the complexes. This result supports the shift of $v_{(\mathrm{C} \equiv N)}$ stretching vibrational band. Such frequency shifts have been observed for the other cyanide complexes [15, 16, 19, 24]. The representative illustrations of the complexes are shown in Scheme 2. 
Table 1. The modes of vibration of the etim in the complexes $\left(\mathrm{cm}^{-1}\right)$.

\begin{tabular}{|c|c|c|c|c|c|c|c|}
\hline \multirow[t]{2}{*}{ Assignments [20] } & \multirow[t]{2}{*}{ Etim (liquid) } & \multicolumn{2}{|c|}{$\mathrm{Cu}-\mathrm{Ni}$-etim } & \multicolumn{2}{|c|}{$\mathrm{Zn}-\mathrm{Ni}$-etim } & \multicolumn{2}{|c|}{ Cd-Ni-etim } \\
\hline & & FT-IR & Raman & FT-IR & Raman & FT-IR & Raman \\
\hline$v_{(\mathrm{NH})}(99)$ & $3153 \mathrm{w}$ & 3316 vs & $3162 \mathrm{~m}$ & $3189 \mathrm{w}$ & $3196 \mathrm{vw}$ & 3419 vs & $3414 \mathrm{w}$ \\
\hline$v_{(\mathrm{CH})}(97)$ & $3136 \mathrm{vw}$ & $3154 \mathrm{w}$ & - & $3136 \mathrm{w}$ & $3134 \mathrm{~s}$ & $3138 \mathrm{w}$ & $3171 \mathrm{w}$ \\
\hline $\mathrm{V}_{\mathrm{as}(\mathrm{CH} 3)}(98)$ & $3110 \mathrm{w}$ & $3120 \mathrm{vw}$ & - & $3112 \mathrm{vw}$ & 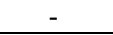 & - & $3141 \mathrm{w}$ \\
\hline$v_{\mathrm{s}(\mathrm{CH} 3)}(99)$ & $3046 \mathrm{w}$ & $3021 \mathrm{w}$ & - & $3020 \mathrm{sh}$ & $3015 \mathrm{sh}$ & - & $3010 \mathrm{w}$ \\
\hline$v_{\mathrm{as}(\mathrm{CH} 2)}(96)$ & $2981 \mathrm{~m}$ & $2978 \mathrm{~m}$ & $2985 \mathrm{w}$ & $2978 \mathrm{~m}$ & - & $2973 \mathrm{w}$ & $2970 \mathrm{w}$ \\
\hline$v_{\mathrm{s}(\mathrm{CH} 2)}(98)$ & $2894 \mathrm{w}$ & $2938 \mathrm{w}$ & $2934 \mathrm{~m}$ & $2938 \mathrm{w}$ & 2938 vs & $2932 \mathrm{w}$ & $2939 \mathrm{~m}$ \\
\hline$v_{(\mathrm{C}=\mathrm{N})}(90)$ & $1675 \mathrm{w}$ & $1708 \mathrm{w}$ & - & - & $1718 \mathrm{vw}$ & $1691 \mathrm{vw}$ & - \\
\hline$v_{(\mathrm{C}-\mathrm{N})}(86)$ & 1576 vs & $1567 \mathrm{vs}$ & $1564 \mathrm{w}$ & $1575 \mathrm{~m}$ & - & $1561 \mathrm{vs}$ & $1561 \mathrm{vw}$ \\
\hline$v_{(\mathrm{C}-\mathrm{N})}(87)$ & $1483 \mathrm{w}$ & $1497 \mathrm{vw}$ & $1495 \mathrm{vs}$ & $1499 \mathrm{sh}$ & 1498 vs & $1498 \mathrm{w}$ & $1497 \mathrm{~s}$ \\
\hline$v_{(\mathrm{C}-\mathrm{N})}(86)$ & $1453 \mathrm{vs}$ & 1464 vs & - & $1456 \mathrm{vs}$ & 1474 vs & $1465 \mathrm{~m}$ & - \\
\hline$v_{(\mathrm{C}-\mathrm{C})}(96)$ & $1431 \mathrm{w}$ & $1436 \mathrm{vw}$ & $1438 \mathrm{w}$ & - & 1442 vs & $1430 \mathrm{~s}$ & $1433 \mathrm{w}$ \\
\hline$v_{(C-C)}(96)$ & $1395 \mathrm{~m}$ & $1383 \mathrm{~m}$ & - & $1390 \mathrm{vw}$ & $1395 \mathrm{vw}$ & $1391 \mathrm{vw}$ & - \\
\hline$\delta_{(\mathrm{NH})}(78), \delta$ & $1375 \mathrm{vw}$ & - & - & $1376 \mathrm{w}$ & $1377 \mathrm{w}$ & $1382 \mathrm{vw}$ & - \\
\hline $\mathrm{R}$ bend1 ( 7 & $32 \mathrm{~m}$ & $1364 \mathrm{w}$ & $1363 \mathrm{~m}$ & - & - & $1366 \mathrm{w}$ & $1366 \mathrm{w}$ \\
\hline R bend2 $(72), \delta_{(\mathrm{CC})}(20)$ & $12 \mathrm{w}$ & $1318 \mathrm{~m}$ & $1320 \mathrm{w}$ & $1320 \mathrm{~s}$ & $1318 \mathrm{w}$ & $1319 \mathrm{w}$ & $1311 \mathrm{vw}$ \\
\hline$\delta_{(\mathrm{CH})}(78), \delta_{(\mathrm{CN})}(20)$ & $1260 \mathrm{vw}$ & $1291 \mathrm{w}$ & $1289 \mathrm{w}$ & - & $1276 \mathrm{vw}$ & $1273 \mathrm{w}$ & $1276 \mathrm{vw}$ \\
\hline$\delta_{(\mathrm{CH})}(88), \delta_{(\mathrm{Cl})}$ & $1245 \mathrm{vw}$ & $1237 \mathrm{w}$ & $1231 \mathrm{vw}$ & $1247 \mathrm{~m}$ & $1240 \mathrm{w}$ & $1232 \mathrm{w}$ & $1226 \mathrm{vw}$ \\
\hline$\delta_{(\mathrm{CH} 3)}(98)$ & $1165 \mathrm{vw}$ & $1200 \mathrm{vw}$ & - & $1176 \mathrm{~m}$ & $1176 \mathrm{~m}$ & $1207 \mathrm{vw}$ & $1200 \mathrm{vw}$ \\
\hline$\delta_{(\mathrm{CH} 3)}$ & $1154 \mathrm{w}$ & $1154 \mathrm{w}$ & - & $1144 \mathrm{~s}$ & $1144 \mathrm{~s}$ & $1158 \mathrm{w}$ & - \\
\hline$\delta_{(\mathrm{CH} 3)}(99)$ & & $1132 \mathrm{w}$ & $1136 \mathrm{~m}$ & - & - & $1132 \mathrm{w}$ & $1131 \mathrm{~m}$ \\
\hline $\mathrm{r}_{(\mathrm{CH} 2)}(71)$, & $1105 \mathrm{vs}$ & $1111 \mathrm{vs}$ & $1108 \mathrm{vw}$ & $1122 \mathrm{vw}$ & - & $1105 \mathrm{vs}$ & - \\
\hline$\omega_{(\mathrm{NH})}(62$ & 1052 vs & 1054 vs & $1062 \mathrm{w}$ & 1054 vs & $1063 \mathrm{~m}$ & $1057 \mathrm{vs}$ & $1056 \mathrm{w}$ \\
\hline 74) & $1009 \mathrm{~m}$ & $1007 \mathrm{vw}$ & $1008 \mathrm{w}$ & $1012 \mathrm{vw}$ & $1034 \mathrm{~m}$ & $1007 \mathrm{vw}$ & $1007 \mathrm{w}$ \\
\hline $\mathrm{r}_{(\mathrm{CH} 3)}(76)$ & 957 & $961 \mathrm{w}$ & $959 \mathrm{w}$ & $953 \mathrm{~m}$ & $959 \mathrm{~m}$ & $966 \mathrm{w}$ & $965 \mathrm{w}$ \\
\hline & 91 & $930 \mathrm{vw}$ & $929 \mathrm{~m}$ & $929 \mathrm{vw}$ & $930 \mathrm{w}$ & $927 \mathrm{w}$ & $928 \mathrm{w}$ \\
\hline$\delta_{(\mathrm{CC})}(7$ & 796 & $853 \mathrm{w}$ & $852 \mathrm{vw}$ & 842 vw & $842 \mathrm{w}$ & $858 \mathrm{~m}$ & $854 \mathrm{vw}$ \\
\hline$\omega_{(\mathrm{CH})}(63)$, & & $756 \mathrm{vs}$ & $756 \mathrm{vw}$ & $760 \mathrm{~s}$ & $784 \mathrm{vw}$ & $780 \mathrm{w}$ & $790 \mathrm{vw}$ \\
\hline$\delta_{(\mathrm{CC})}(72), \delta_{(}$ & & $721 \mathrm{~s}$ & $721 \mathrm{vw}$ & 743 vs & $739 w$ & 747 vs & $748 \mathrm{vw}$ \\
\hline$\tau \mathrm{R} \mathrm{bc}$ & 653 & $652 \mathrm{w}$ & $651 \mathrm{~s}$ & $655 \mathrm{w}$ & $656 \mathrm{~s}$ & $642 \mathrm{~m}$ & $659 \mathrm{w}$ \\
\hline$\tau \mathrm{R}$ bend $2(61)$ & $626 \mathrm{vw}$ & $625 \mathrm{vw}$ & - & - & - & $607 \mathrm{~m}$ & - \\
\hline
\end{tabular}

Abbreviations: $v$-stretching; $v_{\text {as }}-$ asymmetricstretching; $v_{\mathrm{s}}-$ symmetricstretching; $\delta$ - bending; $\omega-$ out-of-plane bending; $\mathrm{R}$ - ring; $\mathrm{r}$-rocking.

Table 2. The modes of vibration of the $\left[\mathrm{Ni}(\mathrm{CN})_{4}\right]^{2-}$ group in the complexes $\left(\mathrm{cm}^{-1}\right)$.

\begin{tabular}{|c|c|c|c|c|}
\hline Assignments $[22]$ & $\mathrm{K}_{2}\left[\mathrm{Ni}(\mathrm{CN})_{4}\right] \cdot \mathrm{H}_{2} \mathrm{O}$ & $\mathrm{Cu}-\mathrm{Ni}$-etim & $\mathrm{Zn}-\mathrm{Ni}$-etim & Cd-Ni-etim \\
\hline $\mathrm{A}_{1 \mathrm{~g}}, v_{(\mathrm{CN})}$ & $(2160) \mathrm{vs}$ & $(2166) \mathrm{vs}$ & $(2182) \mathrm{vs}$ & $(2156) \mathrm{vs}$ \\
\hline $\mathrm{B}_{1 \mathrm{~g}}, v_{(\mathrm{CN})}$ & $(2137) \mathrm{m}$ & $(2131) \mathrm{m}$ & $(2142) \mathrm{m}$ & - \\
\hline $\mathrm{E}_{\mathrm{u}}, v_{(\mathrm{CN})}$ & $2120 \mathrm{vs}$ & $2173 \mathrm{~s}, 2160 \mathrm{~s}, 2135 \mathrm{vs}, 2128 \mathrm{vs}$ & $2173 \mathrm{vs}, 2143 \mathrm{sh}$ & $2142 \mathrm{vs}$ \\
\hline$v_{(}^{13}(\mathrm{CN}$ & $2084 \mathrm{vw}$ & $2090 \mathrm{vw}$ & - & - \\
\hline $\mathrm{E}_{\mathrm{u}}, v_{(\mathrm{NiC})}$ & $542 \mathrm{w}$ & $548 \mathrm{vW}$ & $558 \mathrm{vw}$ & $542 \mathrm{vw}$ \\
\hline $\mathrm{A}_{2 \mathrm{u}}, \pi_{(\mathrm{NiCN})}$ & $443 \mathrm{w}$ & $441 \mathrm{vw}$ & $477 \mathrm{vw}$ & $461 \mathrm{w}$ \\
\hline $\mathrm{E}_{\mathrm{u}}, \delta_{(\mathrm{NiCN})}$ & $414 \mathrm{vs}$ & $414 \mathrm{vs}$ & $426 \mathrm{vs}$ & $424 \mathrm{vs}$ \\
\hline
\end{tabular}

The symbols $v, \delta$ and $\pi$ refer to valence, in-plane and out-of-plane vibrations, respectively. s strong, m medium, $w$ weak, sh shoulder, $\mathrm{v}$ very. The bands observed in the Raman spectra are given in parentheses. 


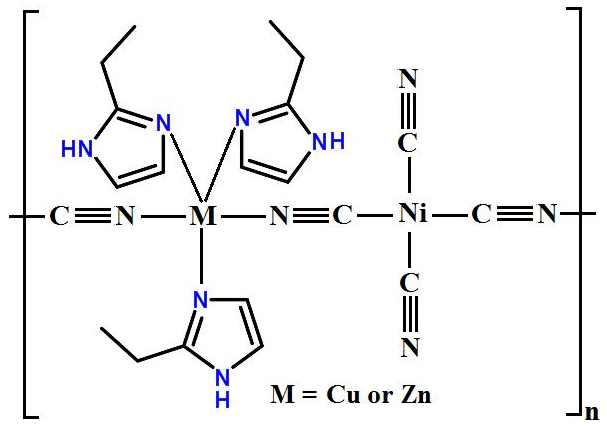

(a)

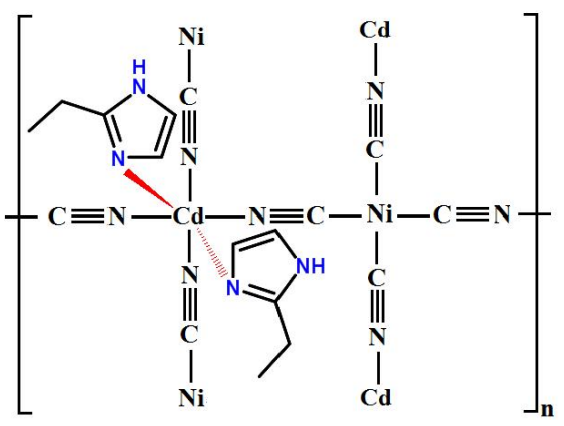

(b)

Scheme 2. The representative illustration of the $\mathrm{Cu}-\mathrm{Ni}$-etim and the $\mathrm{Zn}-\mathrm{Ni}$-etim (a) and the $\mathrm{Cd}-\mathrm{Ni}$-etim (b). The water molecule is not shown in the $\mathrm{Zn}-\mathrm{Ni}$-etim.

\section{Thermal analysis}

Thermal decomposition behaviors of the complexes were performed in temperature range 30 $700{ }^{\circ} \mathrm{C}$ in static air atmosphere. Thermoanalytical data and thermal decomposition curves of the complexes are given in Table 3 and Figures 3-5, respectively. Thermal decomposition of the complexes proceeds in the three stages. In the first stage, the $\mathrm{Cu}-\mathrm{Ni}$-etim and the $\mathrm{Cd}-\mathrm{Ni}$-etim complexes lose the one etim ligand in a single step in the temperature range of $161-192{ }^{\circ} \mathrm{C}$ for the $\mathrm{Cu}-\mathrm{Ni}$-etim and $98-291{ }^{\circ} \mathrm{C}$ for the $\mathrm{Cd}-\mathrm{Ni}$-etim, but the $\mathrm{Zn}-\mathrm{Ni}$-etim complex loses one water molecule between 30 and $160{ }^{\circ} \mathrm{C}$. In the second stage, the endothermic peaks in the temperature range $192-407{ }^{\circ} \mathrm{C}$ for the $\mathrm{Cu}-\mathrm{Ni}$-etim and $160-463{ }^{\circ} \mathrm{C}$ for the $\mathrm{Zn}$-Ni-etim correspond to the loss of the two etim ligands but in the temperature range $291-407{ }^{\circ} \mathrm{C}$ for the $\mathrm{Cd}-\mathrm{Ni}-$ etim are released the one etim ligand. These values were found as following; the two etim ligands for the $\mathrm{Cu}-\mathrm{Ni}-$ etim and the $\mathrm{Zn}-\mathrm{Ni}$-etim, the one etim ligand for the $\mathrm{Cd}-\mathrm{Ni}$-etim [found (calcd.) $(\%)=35.17$ (37.35) for the $\mathrm{Cu}-\mathrm{Ni}$-etim, 33.05 (35.96) for the $\mathrm{Zn}-\mathrm{Ni}$-etim and 19.64 (20.56) for the $\mathrm{Cd}-\mathrm{Ni}$-etim]. In the following stages of the $\mathrm{Cu}-\mathrm{Ni}-$ etim and the $\mathrm{Cd}-\mathrm{Ni}-$ etim complexes, the remaining four cyanide groups decompose as exothermic in the $407-476^{\circ} \mathrm{C}$ temperature range for the $\mathrm{Cu}-\mathrm{Ni}-$ etim and in the $407-435^{\circ} \mathrm{C}$ temperature range for the $\mathrm{Cd}-\mathrm{Ni}-$ etim. In the next step in the $\mathrm{Zn}-\mathrm{Ni}$-etim complex, the remaining four cyanide groups and the one etim ligand decompose between 463 and $504{ }^{\circ} \mathrm{C}$. The final decomposition products were identified as $\mathrm{CuO}$ and $\mathrm{NiO}$ for the $\mathrm{Cu}-\mathrm{Ni}-$ etim, $\mathrm{ZnO}$ and $\mathrm{NiO}$ for the $\mathrm{Zn}-\mathrm{Ni}-$ etim and $\mathrm{CdO}$ and $\mathrm{NiO}$ for the $\mathrm{Cd}-\mathrm{Ni}$-etim [found (calcd.) $(\%)=28.78$ (29.96) for the $\mathrm{Cu}-\mathrm{Ni}-$ etim, 28.42 (29.19) for the $\mathrm{Zn}-\mathrm{Ni}$-etim and 42.08 (43.45) for the $\mathrm{Cd}-\mathrm{Ni}$-etim]. The thermal decomposition products were identified by FT-IR spectroscopy. 
Table 3. Thermoanalytical data of the complexes.

\begin{tabular}{|c|c|c|c|c|c|c|c|c|c|}
\hline \multirow[t]{2}{*}{ Complexes } & \multirow[t]{2}{*}{ Stage } & \multirow{2}{*}{$\begin{array}{c}\text { Temperature } \\
\text { range }\left({ }^{\circ} \mathrm{C}\right)\end{array}$} & \multirow{2}{*}{$\begin{array}{c}\text { DTG }_{\max } \\
\left({ }^{\circ} \mathrm{C}\right)\end{array}$} & \multirow{2}{*}{$\begin{array}{l}\text { Removed } \\
\text { group }\end{array}$} & \multicolumn{2}{|c|}{ Mass loss \% } & \multicolumn{2}{|c|}{ Mass loss $\%$} & \multirow[t]{2}{*}{ Residue } \\
\hline & & & & & Calculated & Found & Calculated & Found & \\
\hline$\left[\mathrm{Cu}(\text { etim })_{3} \mathrm{Ni}(\mathrm{CN})_{4}\right]$ & 1 & $161-192$ & $174(+)$ & etim & 18.67 & 16.29 & & & \\
\hline$\left[\mathrm{Cu}(\text { etim })_{2} \mathrm{Ni}(\mathrm{CN})_{4}\right]$ & 2 & $192-407$ & $195(+)$ & $2(\mathrm{etim})$ & 37.35 & 35.17 & & & \\
\hline$\left[\mathrm{CuNi}(\mathrm{CN})_{4}\right]$ & 3 & $407-476$ & $411(-)$ & $4(\mathrm{CN})$ & 20.21 & 19.76 & 29.96 & 28.78 & $\mathrm{CuO}+\mathrm{NiO}$ \\
\hline$\left[\mathrm{Zn}(\text { etim })_{3} \mathrm{Ni}(\mathrm{CN})_{4}\right] \cdot \mathrm{H}_{2} \mathrm{O}$ & 1 & $30-160$ & - & $\mathrm{H}_{2} \mathrm{O}$ & 3.37 & 2.95 & & & \\
\hline$\left[\mathrm{Zn}(\mathrm{etim})_{3} \mathrm{Ni}(\mathrm{CN})_{4}\right]$ & 2 & $160-463$ & - & $2($ etim $)$ & 35.96 & 33.05 & & & \\
\hline$\left[\mathrm{Zn}(\right.$ etim $\left.) \mathrm{Ni}(\mathrm{CN})_{4}\right]$ & 3 & $463-504$ & $467(-)$ & etim $+4(\mathrm{CN})$ & 37.42 & 35.13 & 29.19 & 28.42 & $\mathrm{ZnO}+\mathrm{NiO}$ \\
\hline$\left[\mathrm{Cd}(\text { etim })_{2} \mathrm{Ni}(\mathrm{CN})_{4}\right]$ & 1 & $98-291$ & $287(+)$ & etim & 20.56 & 19.92 & & & \\
\hline$[\mathrm{Cd}($ etim $) \mathrm{Ni}(\mathrm{CN}) 4]$ & 2 & $291-407$ & $320(+)$ & etim & 20.56 & 19.64 & & & \\
\hline$\left[\mathrm{CdNi}(\mathrm{CN})_{4}\right]$ & 3 & $407-435$ & $419(-)$ & $4(\mathrm{CN})$ & 22.26 & 20.81 & 43.45 & 42.08 & $\mathrm{CdO}+\mathrm{NiO}$ \\
\hline
\end{tabular}

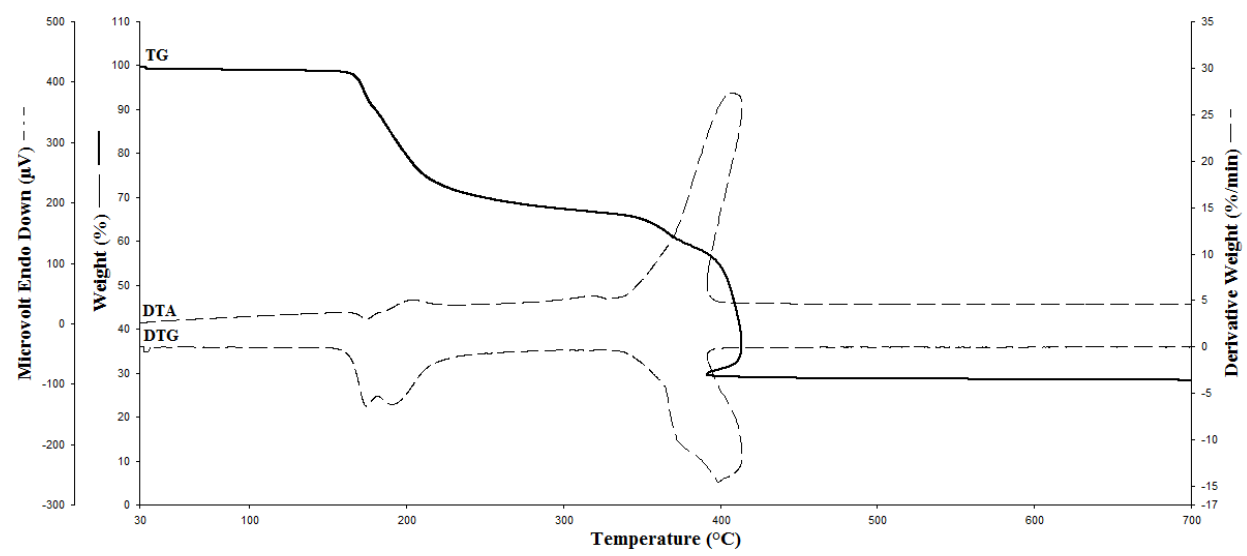

Figure 3. The TG, DTG and DTA curves of the $\mathrm{Cu}-\mathrm{Ni}$-etim.

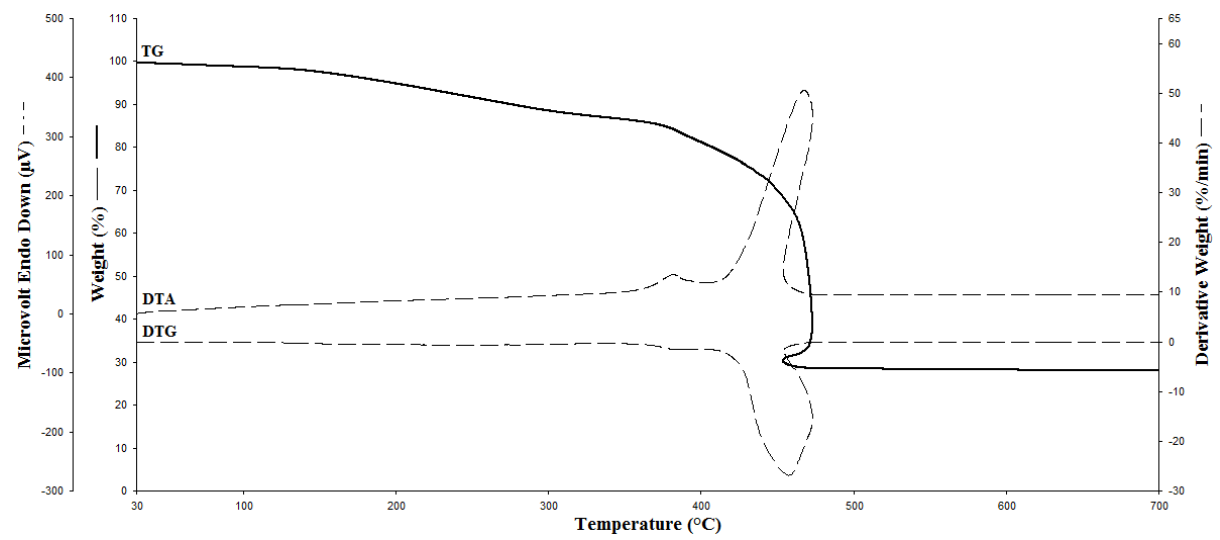

Figure 4. The TG, DTG and DTA curves of the Zn-Ni-etim.

Bull. Chem. Soc. Ethiop. 2016, 30(2) 


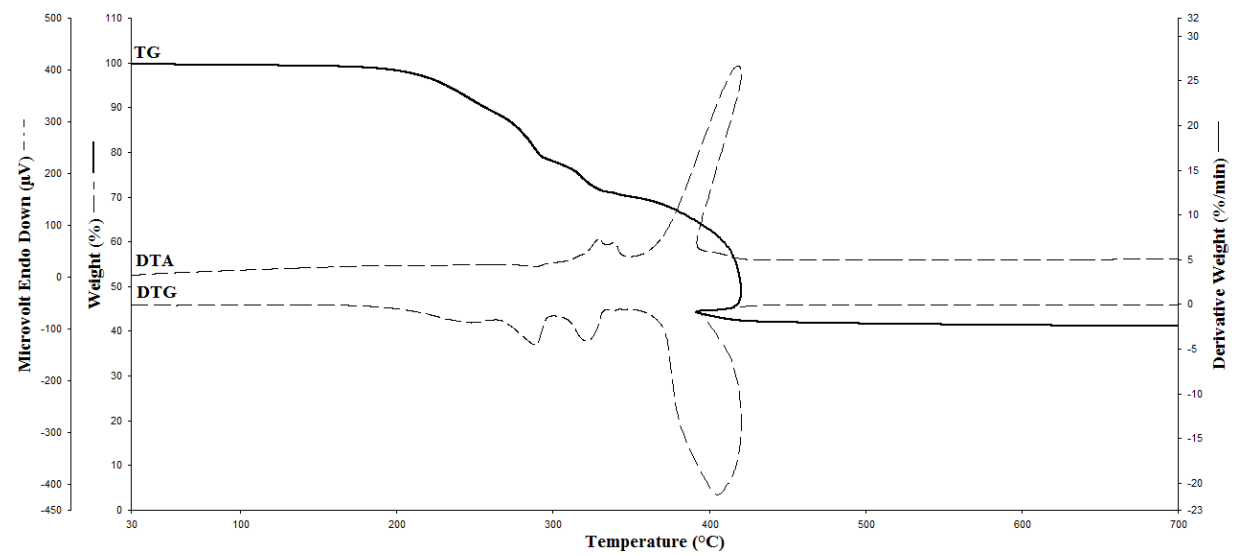

Figure 5. The TG, DTG and DTA curves of the Cd-Ni-etim.

\section{CONCLUSION}

In this study, we synthesized the three new heteronuclear polymeric complexes, $\left[\mathrm{Cu}(\text { etim })_{3} \mathrm{Ni}(\mathrm{CN})_{4}\right]_{\mathrm{n}}, \quad\left\{\left[\mathrm{Zn}(\text { etim })_{3} \mathrm{Ni}(\mathrm{CN})_{4}\right] \cdot \mathrm{H}_{2} \mathrm{O}\right\}_{\mathrm{n}}$ and $\left[\mathrm{Cd}(\text { etim })_{2} \mathrm{Ni}(\mathrm{CN})_{4}\right]_{\mathrm{n}}$. We investigated these complexes using vibration (FT-IR and Raman) spectroscopy, thermal and elemental analyses techniques. On the basis of the spectroscopic results, we suggest that the polymeric structures of the $\mathrm{Cu}-\mathrm{Ni}-$ etim and the $\mathrm{Zn}-\mathrm{Ni}$-etim complexes consist of $1 \mathrm{D}$ coordination polymer, while the $\mathrm{Cd}-\mathrm{Ni}$-etim complex presents a 2D network. The $\mathrm{Ni}(\mathrm{II})$ ion is four coordinate with four cyanide-carbon atoms in a square-planar geometry. Furthermore, the $\mathrm{Cu}(\mathrm{II})$ and $\mathrm{Zn}(\mathrm{II})$ ions are five coordinate with the three etim ligands and the two bridging cyanide groups, whereas the $\mathrm{Cd}(\mathrm{II})$ ion is six coordinate with the two etim ligands and the four bridging cyanide groups. We also showed that thermal analyses of the complexes support the spectroscopic results.

\section{ACKNOWLEDGEMENT}

This paper is dedicated to Prof. Dr. Ziya Kantarci, who died on January, 2012.

\section{REFERENCES}

1. Sharpe, A.G. The Chemistry of Cyano Complexes of the Transition Metals, Academic Press: London; 1976.

2. Hofmann, K.A.; Küspert, F. Z. Anorg. Allgem. Chem. 1897, 15, 204.

3. Cernak, J.; Orendac, M.; Potocnak, I.; Chomic, J.; Orendacova, A.; Skorsepa, J.; Feher, A. Coord. Chem. Rev. 2002, 224, 51.

4. Sopková, A.; Reháková, M.; Śály, V. J. Incl. Phenom. 1989, 7, 401.

5. Kämper, M.; Wagner, M.; Weiß, A. Angew. Chem. 1979, 91, 517.

6. Lescouëzec, R.; Vaissermann, J.; Ruiz-Pérez, C.; Lloret, F.; Carrasco, R.; Julve, M.; Verdaguer, M.; Dromzee, Y.; Gatteschi, D.; Wernsdorfer, W. Angew. Chem. Int. Ed. 2003, 42, 1483.

7. Şenyel, M.; Sertbakan, T.R.; Kürkçüoğlu, G.S.; Kasap, E.; Kantarc1, Z. J. Inc. Phenom. Macroc. 2001, 39, 175. 
8. Iwamoto, T. J. Incl. Phenom. 1996, 24, 61.

9. Ohba, M.; Okawa, H. Coord. Chem. Rev. 2000, 198, 313.

10. Verdaguer, M.; Bleuzen, A.; Marvaud, V.; Vaissermann, J.; Seuleiman, M.; Desplanches, C.; Scuiller, A.; Train, C.; Garde, R.; Gelly, G. Coord. Chem. Rev. 1999, 190, 1023.

11. Blom, N.; Ludi, A.; Burgi, H.B.; Tichy, K. Acta Crystallogr. C 1984, 40, 1767.

12. Rosenzweig, A.; Cromer, D.T. Acta Crystallogr. 1959, 12, 709.

13. Hussain, M.S.; Al-Arfaj, A.; Naseem Akhtar, M.; Isab, A.A. Polyhedron 1996, 15, 2781.

14. Iwamoto, T. in Inclusion Compounds, Vol. 5, Atwood, J.L.; Davies, J.E.D.; MacNicol D.D. (Eds.), Oxford University Press: Oxford; 1991; chapter 6.

15. Kürkçüoğlu, G.S.; Yeşilel, O.Z.; Çaylı, İ.; Büyükgüngör, O. J. Inorg. Organomet. Polym. 2011, 21, 306.

16. Çaylı, İ.; Kürkçüoğlu, G.S.; Yeşilel, O.Z.; Şahin, O.; Büyükgüngör, O. Polyhedron 2011, 31, 386.

17. Kürkçüoğlu, G.S.; Gör, K.; Büyükgüngör, O. Spectrochim. Acta A 2014, 124, 588.

18. Kurkçüoğlu, G.S.; Yeşilel, O.Z:; Kavlak, İ.; Kurtaran, S.; Büyükgüngör, O. J. Inorg. Organomet. Polym. 2009, 19, 314

19. Çetinkaya, F.; Kürkçüoğlu, G.S.; Yeşilel, O.Z.; Hökelek, T.; Dal, H. Polyhedron 2012, 47, 126.

20. Arivazhagan, M.; Manivel, S.; Jeyavijayan, S.; Meenakshi, R. Spectrochim. Acta A 2015, $134,493$.

21. Kürkçüoğlu, G.S.; Yeşilel, O.Z.; Kavlak, İ.; Büyükgüngör, O. J. Inorg. Organomet. Polym. 2009, 19, 539 .

22. McCullough, R.; Jones, L.; Crosby, G. Spectrochim. Acta 1960, 16, 929.

23. Kazuo, N. Infrared and Raman Spectra of Inorganic and Coordination Compounds. Vol. 1, John Wiley and Sons: New York; 1986, p 978.

24. Karaağaç, D.; Kürkçüoğlu, G.S. Bull. Chem. Soc. Ethiop. 2015, 29, 415. 